\title{
Effects of aqueous extract of Moringa oleifera seed on cadmium-induced reproductive toxicity in male Wistar rats
}

\author{
Olawale O Obembe ${ }^{1}$, Yunus Raji ${ }^{2}$
}

1. Osun State University, Osogbo, Physiology.

2. University of Ibadan, physiology.

\begin{abstract}
Bacground: Moringa oleifera seeds have been reported to increase sexual activity of male rats but its mechanism of action remains unknown.

Objective: Cadmium is a heavy metal that induces reproductive toxicity. To elucidate its possible mechanisms of action, the effects of aqueous extract of Moringa seeds (AEMS) on Cadmium-induced reproductive damage were investigated.

Methods: Thirty male rats (180-200g, $\mathrm{n}=5)$ were grouped as follows: Control, Cadmium (2mg/kg), AEMS (100 and 500mg/ $\mathrm{kg}$ ), Cadmium+100mg $/ \mathrm{kg}$ AEMS and Cadmium+500mg $/ \mathrm{kg}$ AEMS. Single intraperitoneal dose of Cadmium was administered while AEMS was given daily (p.o) for 6 weeks and thereafter sacrificed by cervical dislocation. Sperm variables were examined microscopically while serum was analysed for sex hormones and antioxidants, testicular and epididymal total protein from tissue homogenate. Data were analysed using Students t-test and ANOVA.

Results: Cadmium caused significant decrease in sperm variables. The AEMS decreased sperm motility, count and testosterone. These declines were dose dependent. Total testicular protein was significantly lowered by AEMS but total epididymal protein was not affected. Serum catalase and SOD was reduced by AEMS while MDA increased.

Conclusion: Moringa seeds may exhibit male reproductive toxicity, as observed from its deleterious effect on androgen and sperm variables. It failed to prevent cadmium-induced alteration in reproductive variables and serum antioxidants.

Keywords: Aqueous extract, Moringa oleifera seed, cadmium-induced reproductive toxicity, male Wistar rats.

DOI: https://dx.doi.org/10.4314/ahs.v18i3.23

Cite as: Obembe OO, Raji Y. Effects of aqueous extract of Moringa oleifera seed on cadmium-induced reproductive toxicity in male $W$ istar rats. Afri Health Sci. 2018;18(3): 653-663. https:/ / dx.doi.org/10.4314/abs.v18i3.23
\end{abstract}

\section{Introduction}

Moringa oleifera (Linn) is a medicinal plant that belongs to the family Moringaceae. The plant is widely distributed in the tropics and has been reputed for its wide use in folkloric medicine. It is commonly referred to as the miracle tree because of the beneficial uses of different parts of the plant. Several medicinal properties have been attributed to the plant. The leaves are reputed to have an-
Corresponding author:
Olawale O Obembe, Osun State University, Osogbo, Physiology.
Email: obembe24@yahoo.com

ti-inflammatory and wound healing ${ }^{1}$, antitumor ${ }^{2}$, monoamine modulating ${ }^{3}$, antidiabetic ${ }^{4}$ and antioxidant $\mathrm{t}^{4,5,6}$ properties. Prabsattroo et al. $^{7}$ postulated that Moringa leaves might have beneficial effects in improving male sexual performance in stress-induced sexual dysfunction rats, but could not ascribe a definite underlying mechanism of action.

Moringa oleifera seeds are round, dirty white in colour, and about $1 \mathrm{~cm}$ in diameter. Crude extract of the seed have been used for water treatment and purification ${ }^{8-10}$. They are edible and widely consumed in the northern part of Nigeria. Zade and others ${ }^{11}$ examined the effects of the aqueous seed extract on sexual activity of male rats and reported significant increase in the mounting frequency, intromission frequency and ejaculation latency with re- 
duction in mounting latency, intromission latency and post ejaculatory interval. It also significantly increased the libido and sperm count, and the authors concluded that the seed extract may enhance male sexual behavior in male rats. A definite or possible mechanism of action was also not ascribed to its activity by the authors. Cadmium is a heavy metal that induces reproductive toxicity, causing testicular damage by arresting androgenesis and inducing oxidative stress ${ }^{13}$. To elucidate its possible mechanisms of action, the effects of aqueous extract of Moringa seeds on cadmium-induced reproductive damage in male rats were investigated.

\section{Materials and methods \\ Experimental animals}

A total of 30 male rats (180-200 g) were procured and housed in the Central Animal House, Osun State University, Osogbo. They were kept in well aerated cages and were fed with standard pellet and provided clean water ad libitum. The rat pellets were purchased from Ladokun livestock feeds, Ibadan and contained 21\% protein, $35 \%$ fat, $30 \%$ carbohydrate, $0.8 \%$ phosphorus and $0.8 \%$ calcium. Throughout the experiment, the animals were maintained on a 12 hour light/ 12 hour dark cycle under constant room temperature ( 24 degree Celsius). The rats were acclimatized for two weeks prior to onset of experiment. All procedures in this study conformed to the guiding principles for research involving animals as recommended by the Declaration of Helsinki and the Guiding principles in the care and Use of animals ${ }^{13}$ as amended.

\section{Plant collection and extraction} located in an open field in Ibadan, Oyo State, Nigeria. The plant sample was identified and authenticated at the herbarium of the Federal Research Institute of Nigeria (FRIN), Ibadan, where a specimen was deposited and Voucher number FHI No 111249 assigned. The pods were broken to expose the winged and coated seeds. These coated seeds were then shade dried for several weeks and thereafter individually and manually broken to separate the dried naked seeds from the seed coats. The chaff was discarded while the naked dried seeds were subjected to gravitational force so as to blow off any adhering chaff. The clean white seed were pulverized into a homogeneous powder using an electric blender and
Pods of M. oleifera seeds were collected from the plant

stored in a refrigerator at 10 degree Celsius $\left({ }^{\circ} \mathrm{C}\right)$. Aqueous extract of Moringa oleifera seeds (AEMS) was prepared by dissolving $6 \mathrm{~g}$ of the grinded pulverized seed in $30 \mathrm{ml}$ distilled water at ambient temperature and then kept for 3 days at $10{ }^{\circ} \mathrm{C}$. Thereafter, the mixture was filtered through a $2 \mu \mathrm{m}$ pore filter paper ${ }^{6}$. Freshly prepared AEMS was stored at $10{ }^{\circ} \mathrm{C}$ and used up within 3 days.

\section{Experimental design}

Rats were randomly divided into 6 experimental groups $(\mathrm{n}=5)$ as follows: Control, Cadmium $(2 \mathrm{mg} / \mathrm{kg})$, AEMS $(100$ and $500 \mathrm{mg} / \mathrm{kg}$ ) and Cadmium + AEMS (100 or $500 \mathrm{mg} / \mathrm{kg}$ ). Single intraperitoneal dose of Cadmium was administered while AEMS was administered daily by oral gavage (p.o) for 6 weeks. Dosage of AEMS used is as earlier reported ${ }^{11}$. Rats were thereafter sacrificed by cervical dislocation under sodium pentobartital $(30 \mathrm{mg} / \mathrm{kg}$, i.p) anaesthesia and blood obtained by cardiac puncture ${ }^{14}$. Serum obtained was preserved at $-20^{\circ} \mathrm{C}$ for hormonal assay and biochemical analysis while visceral and sex organs were excised and washed in phosphate buffered saline (PBS) and weighed using a digital weighing scale (EasyWay Medical, England). Contralateral organs were quickly fixed in Bouins fluid for 6 hours and thereafter 10\% paraformaldehyde for histopathotological examination.

\section{Sperm analysis}

The epididymis of rats was excised after sacrifice. The sperm collected from the caudal epididymis were analysed as previously described in the literature ${ }^{15}$. Sperm profile was examined microscopically using Olympus research microscope (Olympus, Japan). Diluted sperm suspension was prepared and progressive forward motility was observed and scored to the nearest 10 on a pre-warmed slide under X40 magnification ${ }^{16}$. Sperm viability (live/ dead ratio) study was assessed using eosin/nigrosin staining technique. Non motile (dead) sperm absorbed stain while the motile (live) sperm remained unstained. Percentage of viable sperm was calculated from this. Improved Neubauer hemocytometer was used to estimate sperm count. Counting was done in five Thoma chambers ${ }^{17}$. Sperm morphology was examined by staining sperm smears on miscroscope slides with two drops of Walls and Ewa stain. The slides were then examined under oil immersion with X100 magnification. The sperm cells with abnormal morphology were counted and the percentage calculated as described by Wyrobek and Bruce ${ }^{18}$. 


\section{Hormonal assay}

Serum obtained from blood samples were used for hormonal and biochemical analysis. Enzyme-linked immunoassay technique was used to measure levels of testosterone, luteinizing hormone and follicle stimulating hormone using kits. The kits were obtained from Calbiotech Inc. (California USA) and contained the respective enzyme label, substrate reagent and quality control sample. The quality control was carried out at the beginning and end of the assay in other to ascertain acceptability with respect to bias and within variations. Tessterone kit used had a sensitivity of $0.075 \mathrm{ng} / \mathrm{ml}$ with intra and inter assay variations of 3.9 and $4.3 \%$ respectively. Luteinizing hormone kit had a sensitivity of $0.12 \mathrm{mIU} / \mathrm{ml}$ with intra and inter variation of 7.6 and $10.83 \%$ while follicle stimulating hormone kit had a sensitivity $0.353 \mathrm{mIU} / \mathrm{ml}$ with intra and inter assay variation of 5.6 and $6.4 \%$.

\section{Biochemical assay}

Assay of biomarkers of oxidative stress was carried out spectrophotometrically on serum obtained. Malondialdehyde (MDA) was according to Uchiyama and Mihara ${ }^{19}$, superoxide dismutase (SOD) according to Sun and Zig$\operatorname{man}^{20}$ and Catalase level as described by Aebi ${ }^{21}$. Total tissue protein of testis and epididymis were estimated spectrophotometrically according to the method described by Lowry et al..$^{22}$ using PBS as standard. The testis and epididymis were washed in ice cold $1.5 \% \mathrm{KCl}$ solution, blotted with filter paper and weighed. They were then chopped into bits and homogenized in four volumes of the homogenizing buffer (PBS, $\mathrm{pH}$ 7.4) using Teflon homogenizer. The resulting homogenate was centrifuged at $10,000 \mathrm{rpm}$ for 10 mins in a cold centrifuge $\left(40^{\circ} \mathrm{C}\right)$ to obtain post-mitochondrion fraction. The supernatant was collected and total protein estimated using Randox proteon kit (Randox Laboratories Ltd, UK).

\section{Statistical analysis}

Data were expressed as mean \pm standard error of mean (SEM). Comparison of means were made by one way analysis of variance (ANOVA) using SPSS version 16 (SPSS Inc., Chicago USA). P $<0.05$ was considered significant.

\section{Results}

Effect of AEMS and cadmium on organ weight

Aqueous extract of M. oleifera seeds (AEMS) had no significant effect on the weights of visceral and sex organs (Table 1). The relative weight of the spleen of rats treated with cadmium and AEMS (100 mg/ kg) was observed to be significantly higher than the control, while spleen weight was relatively higher in all other cadmium treated groups when compared with thecontrol.

Table 1: Relative organ weights (\%) of cadmium and AEMS treated rats

\begin{tabular}{|l|l|l|l|l|l|l|}
\hline $\begin{array}{l}\text { Organ } \\
\text { weight (\%) }\end{array}$ & Control & Cadmium & $\begin{array}{l}100 \mathrm{mg} / \mathrm{kg} \\
\text { AEMS }\end{array}$ & $\begin{array}{l}500 \mathrm{mg} / \mathrm{kg} \\
\text { AEMS }\end{array}$ & $\begin{array}{l}100 \mathrm{mg} / \mathrm{kg} \\
\text { AEMS + Cd }\end{array}$ & $\begin{array}{l}500 \mathrm{mg} / \mathrm{kg} \\
\text { AEMS + Cd }\end{array}$ \\
\cline { 1 - 6 } Liver & $2.81 \pm 0.13$ & $3.11 \pm 0.12$ & $2.82 \pm 0.12$ & $2.24 \pm 0.54$ & $2.59 \pm 0.57$ & $2.28 \pm 0.50$ \\
\hline Kidney & $0.28 \pm 0.02$ & $0.32 \pm 0.03$ & $0.28 \pm 0.01$ & $0.28 \pm 0.01$ & $0.28 \pm 0.01$ & $0.30 \pm 0.01$ \\
\hline Heart & $0.31 \pm 0.12$ & $0.35 \pm 0.02$ & $0.34 \pm 0.01$ & $0.33 \pm 0.02$ & $0.30 \pm 0.01$ & $0.34 \pm 0.01$ \\
\hline Spleen & $0.35 \pm 0.03$ & $0.42 \pm 0.05$ & $0.32 \pm 0.02$ & $0.37 \pm 0.09$ & $0.47 \pm 0.03 *$ & $0.43 \pm 0.06$ \\
\hline Lungs & $0.75 \pm 0.07$ & $0.89 \pm 0.11$ & $0.73 \pm 0.10$ & $0.75 \pm 0.02$ & $0.82 \pm 0.09$ & $0.77 \pm 0.04$ \\
\hline Testis & $0.36 \pm 0.08$ & $0.34 \pm 0.10$ & $0.51 \pm 0.03$ & $0.42 \pm 0.09$ & $0.20 \pm 0.02$ & $0.21 \pm 0.05$ \\
\hline Epididymis & $0.17 \pm 0.04$ & $0.23 \pm 0.07$ & $0.20 \pm 0.02$ & $0.23 \pm 0.03$ & $0.12 \pm 0.02$ & $0.15 \pm 0.03$ \\
\hline $\begin{array}{l}\text { Seminal } \\
\text { Vesicle }\end{array}$ & $0.32 \pm 0.12$ & $0.30 \pm 0.10$ & $0.36 \pm 0.10$ & $0.35 \pm 0.10$ & $0.34 \pm 0.06$ & $0.31 \pm 0.12$ \\
\cline { 1 - 4 } Prostate & $0.11 \pm 0.02$ & $0.08 \pm 0.02$ & $0.12 \pm 0.02$ & $0.12 \pm 0.02$ & $0.10 \pm 0.01$ & $0.11 \pm 0.03$ \\
\hline
\end{tabular}

Values are Mean $\pm \mathrm{SEM}, \mathrm{n}=5 .{ }^{*} \mathrm{P}<0.05$ indicates significant difference from control. 


\section{Effect of AEMS and cadmium on sperm profile}

Table 2 showed that cadmium caused a significant decline in sperm motility, sperm count, sperm volume and sperm viability but did not significantly affect sperm morphology. Moringa seeds caused a dose dependent decline in sperm motility and sperm count. The extract failed to prevent cadmium-induced decline in sperm count, sperm volume and sperm viability. Co-administration of cadmium and AEMS (500 mg/kg) caused a greater toxicity to these sperm variables as the values were apparently lower when compared with cadmium only treated rats. Moringa seeds $(100 \mathrm{mg} / \mathrm{kg})$ significantly ameliorated the cadmium-induced decline in sperm motility, but not the higher dose $(500 \mathrm{mg} / \mathrm{kg})$ of the extract.

Table 2: Sperm variables of cadmium and AEMS treated rats

\begin{tabular}{|l|l|l|l|l|l|l|}
\hline & Control & Cadmium & $\begin{array}{l}100 \mathrm{mg} / \mathrm{kg} \\
\text { AEMS }\end{array}$ & $\begin{array}{l}500 \mathrm{mg} / \mathrm{kg} \\
\text { AEMS }\end{array}$ & $\begin{array}{l}100 \mathrm{mg} / \mathrm{kg} \\
\text { AEMS + Cd }\end{array}$ & $\begin{array}{l}500 \mathrm{mg} / \mathrm{kg} \\
\text { AEMS + Cd }\end{array}$ \\
\hline $\begin{array}{l}\text { Sperm } \\
\text { motility } \\
(\%)\end{array}$ & $92.00 \pm 1.23$ & $1.24 \pm 0.34^{* *}$ & $74.00 \pm 2.45^{*}$ & $44.40 \pm 14.05^{*}$ & $48.00 \pm 11.58^{*}$ & $1.60 \pm 0.40^{*}$ \\
\hline $\begin{array}{l}\text { Sperm } \\
\text { count } \\
\text { (million/ml) }\end{array}$ & $135.4 \pm 4.82$ & $22.40 \pm 13.15^{*}$ & $99.80 \pm 5.95^{*}$ & $61.20 \pm 15.44^{*} \#$ & $23.30 \pm 13.89^{*}$ & $11.84 \pm 11.04^{*}$ \\
\hline $\begin{array}{l}\text { Abnormal } \\
\text { morphology } \\
(\%)\end{array}$ & 11.77 & $7.06 \pm 3.52$ & $12.53 \pm 0.70$ & $11.56 \pm 2.71$ & $7.11 \pm 3.55$ & $4.41 \pm 3.16^{*}$ \\
\hline $\begin{array}{l}\text { Sperm } \\
\text { volume } \\
\text { (ml) }\end{array}$ & $5.18 \pm 0.02$ & $2.48 \pm 1.08^{*}$ & $5.18 \pm 0.02$ & $4.30 \pm 0.83$ & $2.68 \pm 0.99^{*}$ & $1.82 \pm 0.82^{*}$ \\
\hline $\begin{array}{l}\text { Sperm } \\
\text { viability } \\
(\%)\end{array}$ & $96.80 \pm 0.74$ & $12.80 \pm 7.70^{*}$ & $98.80 \pm 0.74$ & $77.60 \pm 11.72$ & $12.80 \pm 7.70 *$ & $13.00 \pm 11.75$ \\
\hline
\end{tabular}

Values are Mean \pm SEM, $\mathrm{n}=5 .{ }^{*} \mathrm{P}<0.05$ indicates significant difference from control and \# indicates significant difference from lower dose.

Effects of AEMS and cadmium on total tissue protein

When comparisons were made with the control group, AEMS $(100 \mathrm{mg} / \mathrm{kg})$ caused a significant decline in total testicular tissue protein (Figure 1). An apparent decline in total testicular tissue protein was observed in AEMS
$(500 \mathrm{mg} / \mathrm{kg})$ treated rats while rats co-treated with the higher dose AEMS (500 mg/kg) and cadmium also had significantly lower testicular protein. However, none of the treatment regimen had significant effect on the total epididymal tissue protein when compared with the control (Figure 1). 


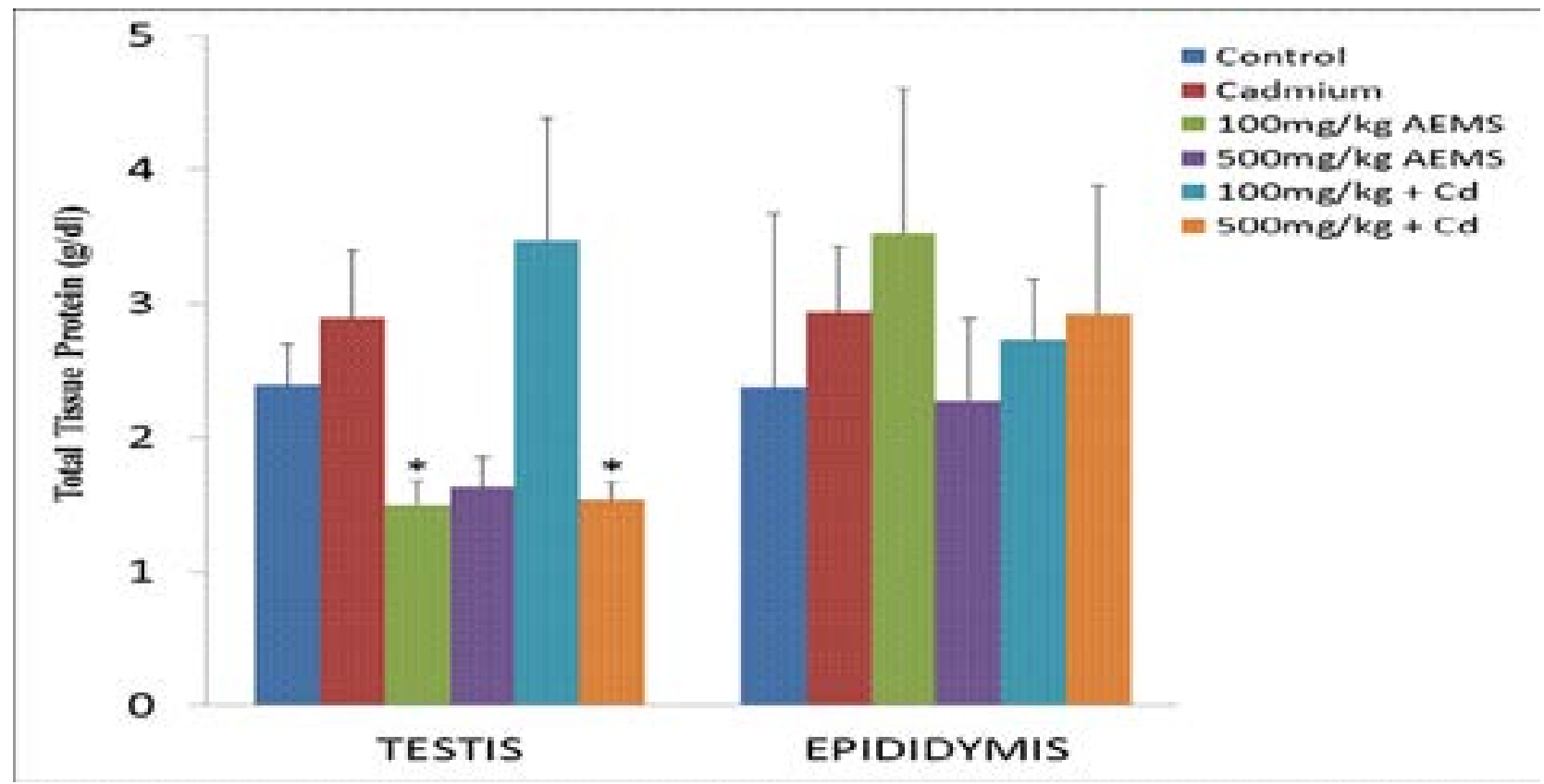

Figure 1: Total tissue protein of Cadmium and AEMS treated rats. . ${ }^{*} \mathrm{P}<0.05$ indicates significant difference from control

\section{Effect of AEMS and cadmium on Sex Hormones}

Cadmium caused a significant decline in serum testosterone level when compared with the control (Figure 2). Moringa seeds (100 and $500 \mathrm{mg} / \mathrm{kg}$ ) caused a similar decline in serum levels of testosterone, and these were sig- nificantly lower than the control. Testosterone levels were also lower in the two groups that received both cadmium and AEMS, but the decline was not statistically significant (Figure 2). Neither cadmium nor AEMS had effect of on serum luteinizing hormone. Other treatment regimen also had no effect on luteinizing hormone level.

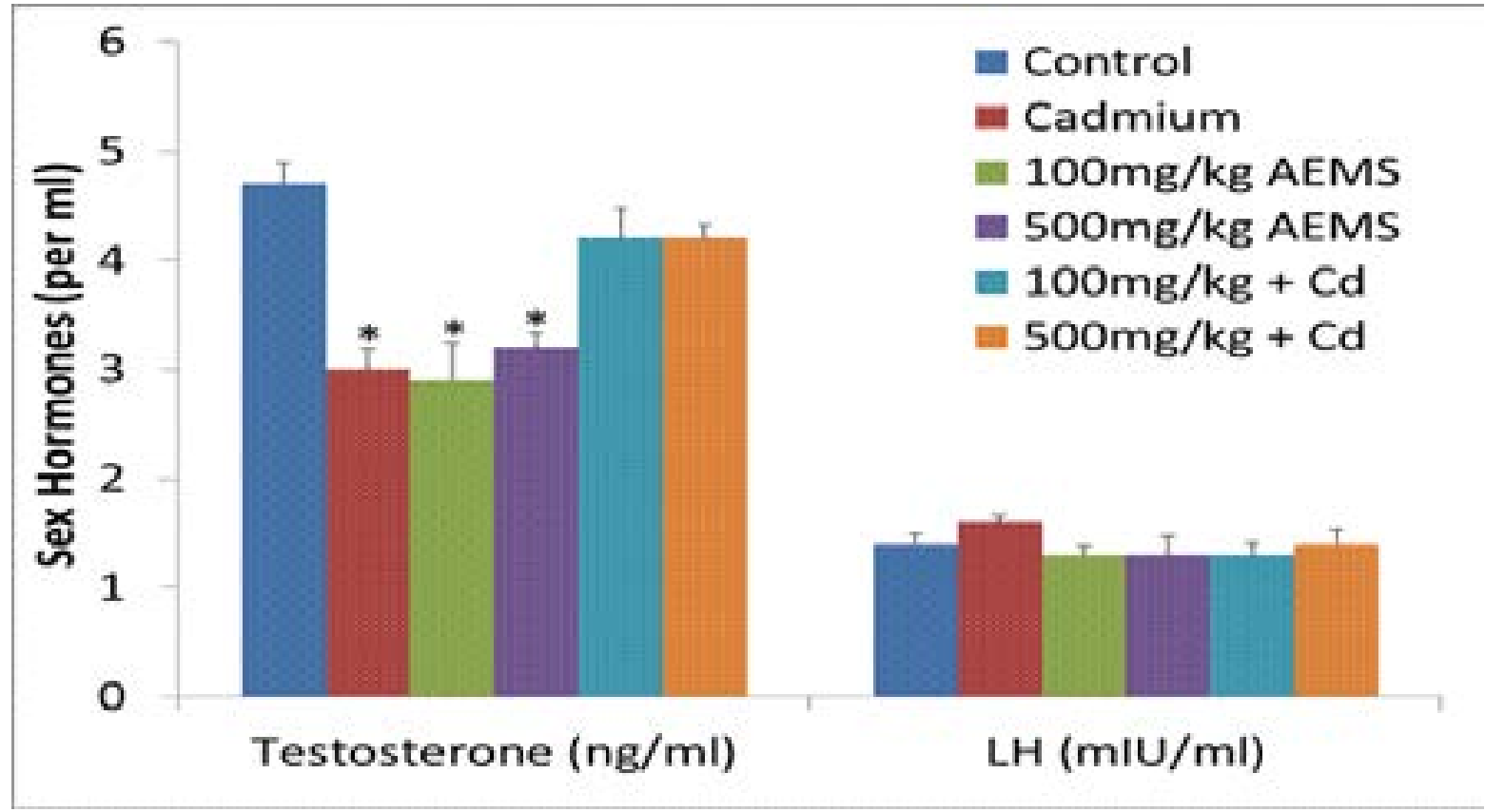

Figure 2: Sex hormones of cadmium and AEMS treated rats. ${ }^{*} \mathrm{P}<0.05$ indicates significant difference from control 
Effect of AEMS and cadmium on Serum Antioxidants

Figure 3 showed that serum level of catalase was significantly increased by cadmium, AEMS (100 and $500 \mathrm{mg} /$ $\mathrm{kg}$ ) and combination of both. Cadmium caused a significant decrease in serum level of SOD, likewise AEMS (500 mg/kg), and therefore failed to prevent cadmium-in- duced decline in SOD. However, treatment with AEMS $(100 \mathrm{mg} / \mathrm{kg})$ did not significantly affect SOD, but it prevented cadmium-induced decline in SOD. Cadmium caused a significant increase in serum MDA, an increase that is similar to that caused by AEMS (500 mg/ $\mathrm{kg}$ ). The apparent increase in MDA in all other groups was not statistically significant (Figure 3).

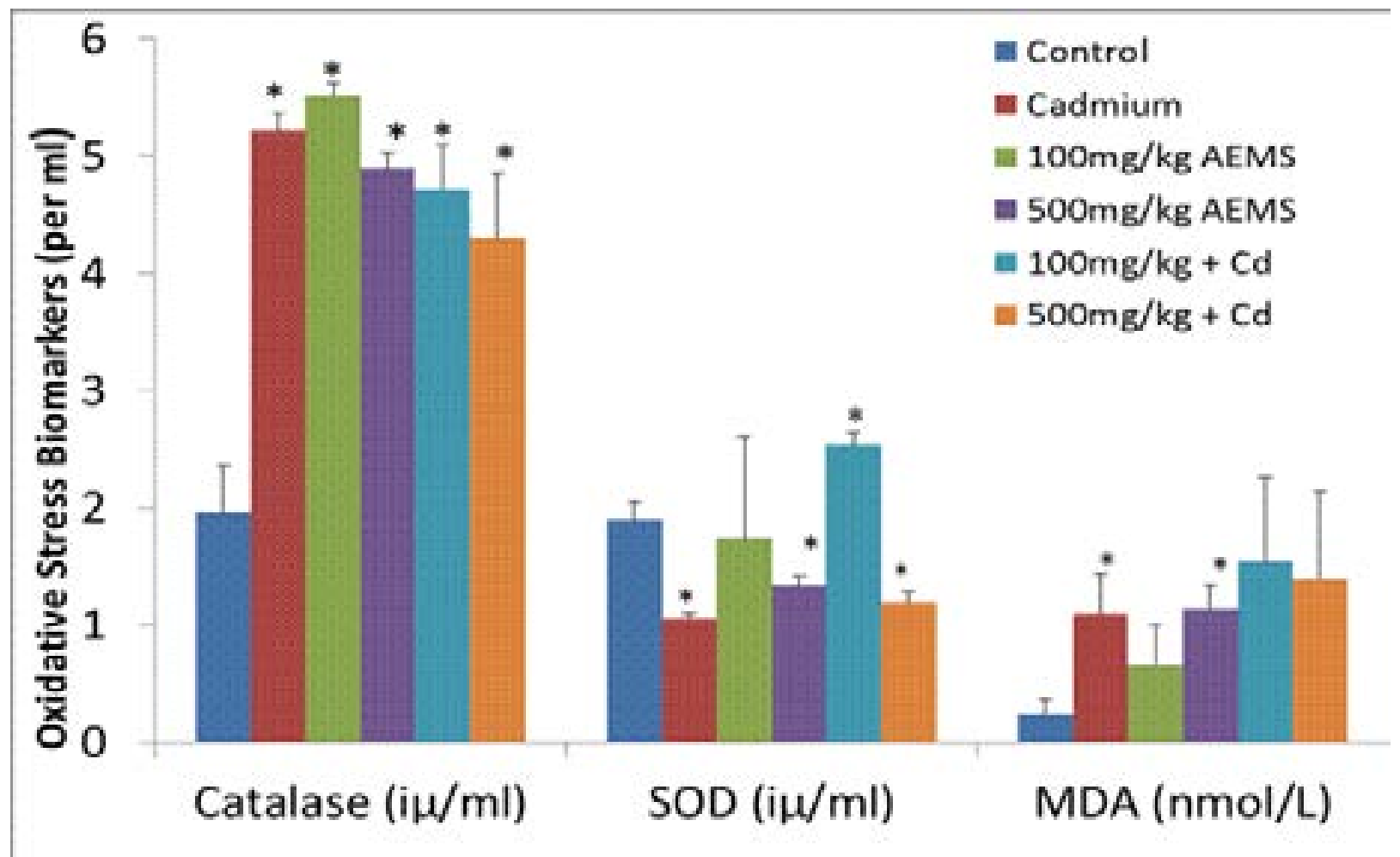

Figure 3: Oxidative stress biomarkers of cadmium and AEMS treated rats. $* \mathrm{P}<0.05$ indicates significant difference from control

Effect AEMS and cadmium on histology of sex organs Histological examination of the reproductive tissues showed varying degrees of degeneration of the semi- niferous tubules of the testis with accompanied loss of spermatogenic cells and spermatids (figure 4) while the epididymis was largely unaffected (figure 5). 

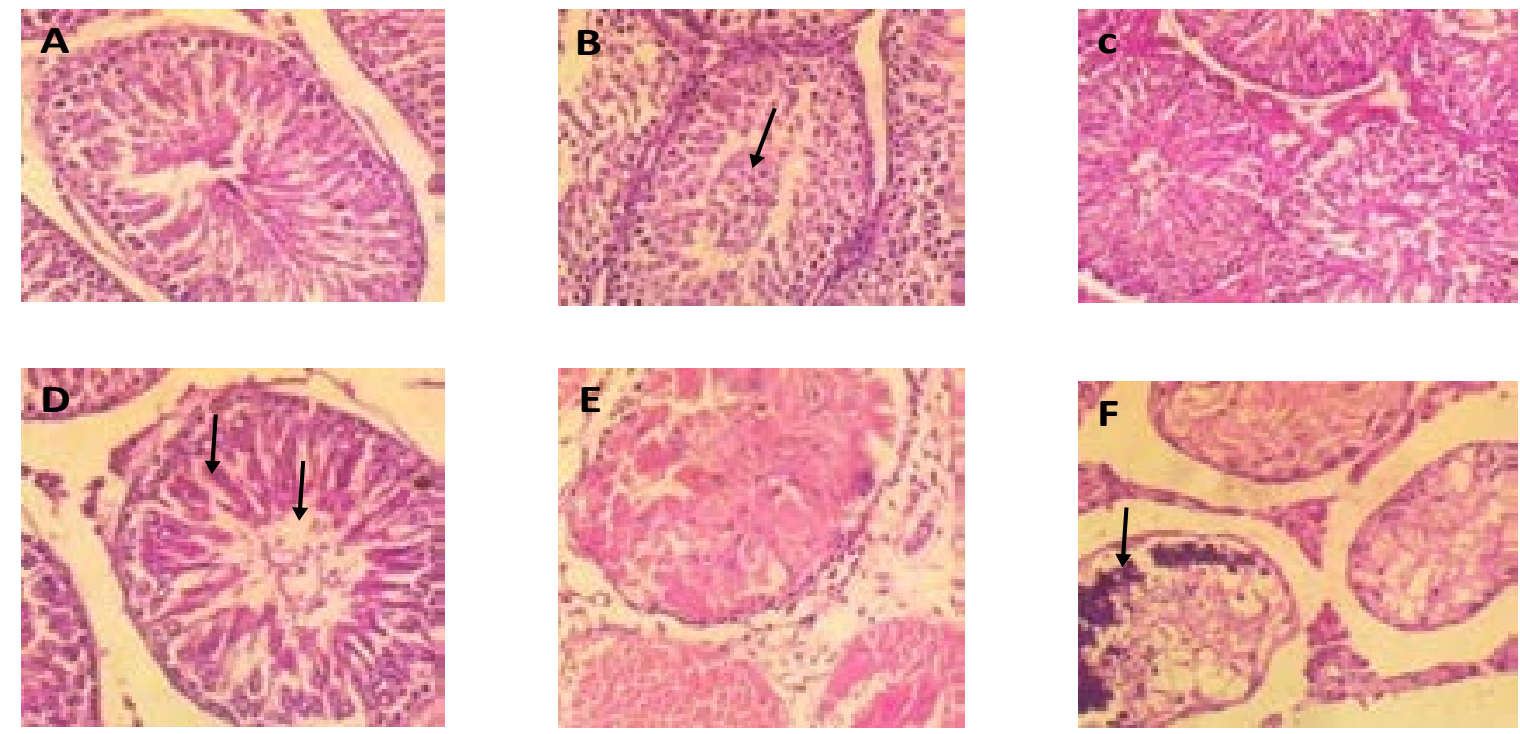

Figure 4: Photomicrograph ( $X$ 400) of a section of testis of Cadmium and AEMS treated rats showing: $\mathbf{A}$ (Control) with normal spermatogenic cells; B (Cadmium only)- Arrow indicates immature spermatogenic cells in the luminal compartment; C $(100 \mathrm{mg} / \mathrm{kg}$ AEMS)-Spermatocytes predominate and spermatids are present; D (1000 mg/kg AEMS)- Arrow indicates depleted Spermatogenic cells, reduced germinal height and widened lumen; $\mathbf{E}(\mathrm{Cd}+100 \mathrm{mg} / \mathrm{kg}$ AEMS $)$ - Seminiferous tubules devoid of discernable lumen and filled with inflammatory cells and dystrophic calcification; F $(\mathrm{Cd}+1000 \mathrm{mg} / \mathrm{kg}$ AEMS $)-$ Seminiferous tubules are degenerated and filled with necrotic debris, inflammatory cells and fibrotic cells.

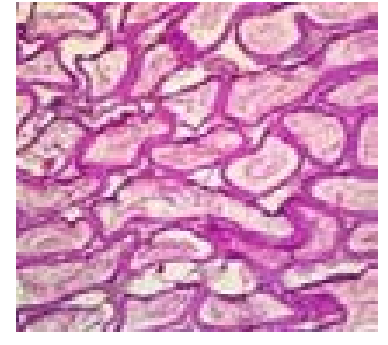

D

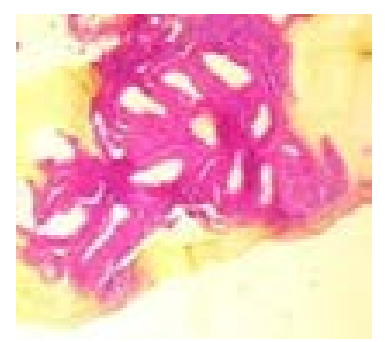

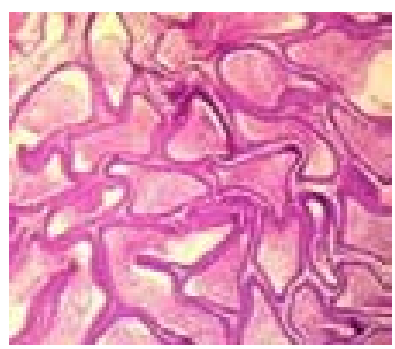

$\mathrm{E}$

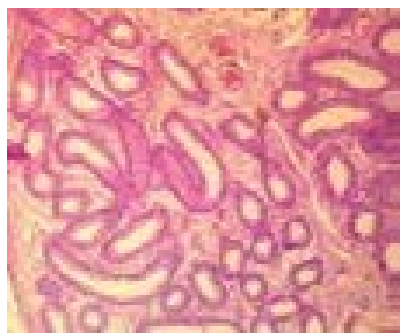

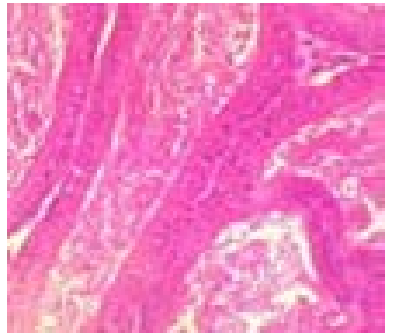

$\mathrm{F}$

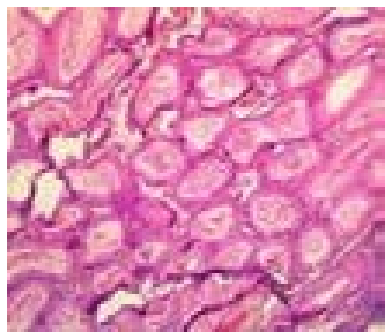

Figure 5: A photomicrograph (X 100) of a section of epididymis of Cadmium and AEMS treated rats showing: A (Control)- with large intact epididymal tubules and normal epithelium and interstitium, No visible lesion observed; B (cadmium only) No visible lesion observed; C (100mg/kg AEMS)- No visible lesion observed;

D $(1000 \mathrm{mg} / \mathrm{kg}$ AEMS)- Epididymal epithelium is normal and lumens contain spermatids; $\mathbf{E}(\mathrm{Cd}+100 \mathrm{mg} / \mathrm{kg}$ AEMS $)-$ Epididymal epithelium is normal but lumens are devoid of spermatids; $\mathbf{F}(\mathrm{Cd}+1000 \mathrm{mg} / \mathrm{kg}$ AEMS $)$ - moderatecongestion of interstitial blood vessels and No visible lesion observed 


\section{Discussion}

The outcome of this study provides to the best of our knowledge the first known scientific data on the actions of M. oleifera seeds on oxidative stress biomarkers and sex hormones of male rats. The aqueous extract of $\mathrm{M}$. oliefera seeds was earlier reported in literature to increase the sexual activity of male rats ${ }^{11}$, but the mechanism of action was unclear. The elucidate the possible mechanism(s) of action of AEMS on male sexual activity, single intraperitoneal dose of cadmium was administered to induce testicular damage, causing a decline in androgen level and inducing oxidative damage. We then sought to determine if AEMS will prevent or ameliorate cadmium-induced reproductive toxicity. The doses of AEMS used in this study were as reported in literature, $500 \mathrm{mg} /$ $\mathrm{kg}$ bw AEMS allegedly having the most pronounced effect on the male sexual activity ${ }^{11}$.

Results from this study showed that contrary to earlier claim, AEMS at both doses administered caused a significant decline in sperm motility and sperm count when compared with the control (Table 2). It had no effect on sperm morphology, sperm volume and sperm viability. Cadmium however also caused a significant decline in sperm motility, sperm count, sperm volume and sperm viability. This is consistent with earlier reports in literature $^{12,23}$. Moringa seeds failed to prevent cadmium-induced decline in these sperm variables, although an ameliorative effect was observed on sperm motility at 100 $\mathrm{mg} / \mathrm{kg}$ dose. Rats treated with a combination of cadmium and AEMS (500 mg/kg) had an apparently greater decline in sperm count and sperm volume when compared with cadmium only treated rats.

Sperm motility and sperm count are reproductive variables that are androgen dependent. The observed decline in serum testosterone level in rats treated with cadmium or either dose of AEMS probably account for the observed decline in these sperm variables of the treated rats. Cadmium induces androgen damage by various mechanisms. This includes inducing genotoxicity by causing molecular apoptosis and necrosis in testicular tissue via alteration of the expression of certain genes such as Caspase, P53, C-Jun and MT-1 ${ }^{24}$ and destabilization of sperm chromatin by blockade of calcium channels and alkalization of the luminal fluid of the seminiferous tu- bules and epididymal duct by inhibition of Leydig cell androgen production and inhibition of sliding movement of the microtubules ${ }^{23,25}$. These probably accounts for the observed decline in sperm motility and sperm count of cadmium treated rats and histopathological derangement of the testis evidenced by multiple seminiferous tubules in which there is loss of thespermatogenic cells at the basal compartment into the luminal compartment. Consequently, immature spermatids which are expected at the basal region predominates the luminal portions. The decline in testosterone in cadmium or AEMS treated rats may not be due to its effect on the pituitary gland, as no effect was observed on luteinizing hormone (figure 2). Cadmium has been reported to inhibit expression of Steroid gene acute regulatory proteins $-\mathrm{St} \mathrm{AR}^{26,27}$ and cause shrinkage of leydig cell nuclei and diminish the amount endoplasmic reticulum, mitochondria and cytoplasmic matrix ${ }^{28-30}$. In addition to causing a decline in testosterone, AEMS also reduced the total testicular protein when compared with the control. Also, histopathological examination of the testes revealed depletion of the spermatogenic cells and erosion of the basal membrane of the seminiferous tubules. However, total epididymal protein of treated rats was not significantly affected and the histology of the epididymis revealed that the extract caused no discernible lesion. Therefore, it is probable that AEMS mediates its toxicity effect on male reproductive system by directly acting on the testis, but not the epididymis.

The action of AEMS on testosterone may probably be mediated by its phytochemical constituents. Phytochemical screening of M. oleifera seeds using water or methanol solvents revealed the presence of alkaloids, saponins, tannins, terpenes, alkaloids, flavonoids, carbohydrates and cardiac glycosides ${ }^{31-33}$. Some of these constituents for example flavonoids and saponins have however been implicated in male reproductive toxicology. Rutin, a flavonoid commonly found in nature, has anti-mitotic, vasoprotective, and antihyperlipidemic activity. When hydrolyzed as quercetin, it causes a decline in epididymal organ weight and promotes inhibition of spermatozoa motility, alterations in the prostate, and in the levels of testosterone and dihydrotestosterone ${ }^{35}$. Also, Maoxin et al. ${ }^{35}$ reported that icariin, a flavonoid isolated from Herba epimedii plant, at higher doses may damage reproductive functions by increasing oxidative stress in the testes, although at 
lower doses within a certain dose range may be beneficial to male reproductive functions. Saponins have also been reported to induce male reproductive toxicity, causing a decrease in weight of sex organs, sperm count, sperm motility and sperm density with histomorphological damage to the sertoli and leydig cells ${ }^{36}$.

Oxidative stress is a general term used to describe a state of damage caused by reactive oxygen species $^{37}$. Reactive oxygen species (ROS) have a high reactivity potential and are therefore toxic and can lead to oxidative damage in cellular macromolecules such as DNA, proteins and lipids $^{38}$. When ROS generation exceeds the antioxidant capacity of cells, oxidative stress develops ${ }^{39}$. The onset of oxidative stress is marked by accumulation of reactive oxygen species ${ }^{40}$. Superoxide dismutase is an enzyme that repairs cells and reduces the damage done to them by superoxide, the most common ROS in the human body. Studies have shown that SOD acts both as an antioxidant and anti-inflammatory agent ${ }^{41}$. Cadmium has been reported to cause an increase in ROS in testicular tissues by decreasing zinc utilization via competitive binding ${ }^{42}$. Zinc enhances testosterone synthesis and scavenges ROS produced in the testicular tissues. In this study, cadmium caused a significant reduction in SOD activity which may be inferred to imply increased generation and accumulation of free radicals such as superoxide. The extract (500 $\mathrm{mg} / \mathrm{kg}$ ) caused a similar decline in SOD activity when compared with the control, and this suggests a potential capability of the extract to induce oxidative damage. SOD has been reported to be easily inactivated by ROS and lipid peroxides ${ }^{43}$. The observed increase in catalase level in all treated rats may probably be due to a reactionary response to the increased superoxide generated (or other free radicals) due to respective treatment. However, SOD level was not affected by low AEMS dose (100 mg/ $\mathrm{kg}$ ) and cadmium-induced decline in SOD was observed to be ameliorated by AEMS at this dose. This is contrary to the observed effect at a higher AEMS dose $(500 \mathrm{mg} /$ $\mathrm{kg})$.

Lipid peroxidation is associated with a wide variety of toxic effects including decreased membrane fluidity and function, impaired functions of the mitochondria, Golgi apparatus and inhibition of enzymes, and these may culminate in production of toxic and reactive free radicals and cell death41. Malondialdehyde (MDA) is an end-product of lipid peroxidation and is frequently measured as an index of these processes ${ }^{44}$. The high increase in the level of MDA in cadmium or AEMS $(500 \mathrm{mg} / \mathrm{kg}$ ) treated groups may indicate lipid peroxidation culminating in generation of superoxides and induction of oxidative damage. This hypothesis is buttressed by the observed decrease in SOD and increase in catalase. Koyu et al. ${ }^{45}$ earlier reported an increase in MDA level in cadmium treated rats. An apparent increase in MDA was observed in other treatment regimen, but not statistically significant.

\section{Conclusion}

Aqueous extract of Moringa oleifera seeds may exhibit male reproductive toxicity, acting majorly on the testis as observed from its deleterious effect on testicular androgen, testicular total protein, sperm variables and the induction of oxidative stress in rats. The extract therefore has no significance in cadmium-induced reproductive toxicity.

\section{Financial support}

This research received no specific grant from any funding agency, commercial or not-for-profit sectors.

\section{Conflict of interest}

None.

\section{Ethical standard}

The authors assert that all procedures contributing to this work comply with the ethical standards relevant national guides on the care and use of laboratory animals (HREC) as approved by the Human and Animal Research Ethical Committee of the Osun State University, Nigeria.

\section{References}

1. Udupa SL, Udupa AL, Kulkarni DR. Studies on anti-inflammatory and wound healing properties of Moringa oleifera and Aegle marmelos. Fitoterapia. 1994; 65: 119-123.

2. Sadek KM, Abouzed TK, Abouelkhair R, Nasr S. The chemo-prophylactic efficacy of an ethanol Moringa oleif- 
era leaf extract against hepatocellular carcinoma in rats. Pharmacentical Biology. 2017; 55(1): 1458-1466.

3. Ganguly R, Guha D. Alteration of brain monoamines and EEG wave pattern in rat model of Alzheimer's disease and protection by Moringa oleifera. Indian J Med Res. 2008; 128(6):744-751.

4. Gupta R, Mathur M, Bajaj VK, Katariya P, Yadav S, Kamal R, Gupta RS. Evaluation of antidiabetic and antioxidant activity of Moringa oleifera in experimental diabetes. J Diabetes. 2012; 4(2):164-71

5. Shaat AR, Sadek KM, El-Far AH, Nasr SM, El-Sayed Y. Evaluation of antioxidant and hepatoprotective activities of moringa (moringa oleifera) leaves in diabetic rabbits. European Journal of Pharmaceutical and Medical Research. 2017; 4(07): 154-162.

6. Sadek KM. Chemotherapeutic efficacy of an ethanolic Moringa oleifera leaf extract against chromium-induced testicular toxicity in rats. Andrologia. 2014; 46, 1047-1054. 7. Prabsattroo T, Wattanathorn J, Iamsaard S, Sompsat P, Sritragool O, Thukhummee W, and Muchimapura S. Moringa oleifera extract enhances sexual performance in stressed rats. J Zhejiang Univ Sci. 2015; 16 (3): 179-190.

8. Marquetotti A, Vieira S, Vieira MF, Silva GF, Araújo ÁA, Fagundes-klen MR, Veit MT. Use of Moringa oleifera Seed as a Natural Adsorbent for Wastewater Treatment. Water Air Soil Pollution. 2010; 206:273-281.

9. Pandey A, Pradheep K, Gupta R, Nayar ER, Bhandari DC. "Drumstick tree" (Moringa oleifera Lam.): a multipurpose potential species in India. Genetic Resources and Crop Evolution. 2010; 58:453-460.

10. Beltran-Heredia J, Sanchez-Martin J, Barrado-Moreno M. Removal of Anionic Surfactants in Aqueous Solutions with Moringa Oleifera Seed Extract Coagulant. Sustainability. 2011; 1-20. PubMed.

11. Zade SV, DabhadkarKD, Thakare GV, Pare RS. Effect of Aqueous Extract of Moringa oleifera Seed on Sexual Activity of Male Albino Rats. Biological Forum - An International Journal. 2013; 5(1): 129-140.

12. Siu ER, Mruk DD, Porto CC, Cheng CY. Cadmium induced testicular injury. Toxicol Appl Pharmacol. 2009; 238(3): 240-249.

13. World Medical Association, American Physiological Society. Guiding principles for research involving animals and human beings. Am. J. Physiol. Regul. Integr. Comp. Physiol. 2002; 283: R281-R283.

14. Institutional Animal Care and Use Committee (IACUC). Austin Guidelines for the use of cervical disloca- tion for Rodent. The University of Texas, 2013; pp 1-2. 15. Obembe OO, Ige AO. Sperm parameters of male Wistar rats treated with Anacardium occidentale L. leaf extract. Research Journal of Health Sciences. 2016; 4(1):83-89. 16. Morrissey RE, Schwetz BA, Lamb JC 4th, Ross MD, Teague JL, Morris RW. Evaluation of rodent sperm, vaginal cytology, and reproductive organ weight data from National Toxicology Program 13-week studies. Fundam Appl Toxicol. 1988; 11(2):343-58. PubMed.

17. Freund M, Carol B. Factors affecting haemocytometer count of sperm concentration in human semen. $J$ Reprod Fertil. 1964; 8: 149-55.

18. Wyrobek AJ, Bruce WR. The induction of sperm shape abnormalities in mice and humans. In: Hollaender A, De Serres FJ. Chemical mutagens Vol. 5. New York: Plenum Press; 1980; p. 257-285.

19. Uchiyama M, Mihara M. Determination of malonaldehyde precursor in tissues by thiobarbituric acid test. Analytical Biochemistry. 1978; 86:271-278.

20. Sun M, Zigman S. An improved spectrophotometric assay for superoxide dismutase based on epinephrineautoxidation. Analytical Biochemistry. 1978; 90, 81-89.

21. Aebi H. Catalase in vitro. Methods in Enzymology. 1984; 105, 121-126.

22. Lowry OH, Rosenbrough NJ, Farr AL, Randall RJ. Protein measurement with Folin phenol reagent. J. Biol. Chem. 1951; 193: 265-75.

23. Kaur S, Sharma S. Evaluation of toxic effect of cadmium on sperm count, sperm motility and sperm abnormality in albino mice. International Journal of Advanced Research. 2015; 3(3): 335-343.

24. Jin YH, Clark AB, Slebos RJ, Al-Refai H, Taylor JA, Kunkel TA, Resnick MA, Gordenin DA. Cadmium is a mutagen that acts by inhibiting mismatch repair. Nat. Genet. 2003; 34(3): 326-329.

25. Kanous KS, Casey C, Lindemann CB. Inhibition of microtubules sliding by $\mathrm{Ni} 2+$ and $\mathrm{Cd} 2+$ : Evidence for a differential response of certain microtubules pairs within the bovine sperm axoneme. Cell Motil. Cytoskeleton. 1993; 26(1): 66-76.

26. Berleu RS, Stadiman ER. Protein oxidative in aging, disease and oxidative stress. J. Biol. Chem. 1997; 272: 20313-20316.

27. Huang BM, Liu MY. Inhibitory actions of lead on steroidogenesis in MA-10 mouse leydig tumor cells. Arch. Androl. 2004; 50(1):5-9.

28. Blanco A, Moyano MR, Molina AM. Quantitative 
study of Leydig cell populations in mice exposed to low doses of cadmium. Bull. Environ. Contam. Toxicol. 2009; 82: 756-760.

29. Predes FD, Monteiro JC, Matta SLP, Garcia MC, Dolder, H. Testicular Histomorphometry and Ultrastructure of Rats Treated with Cadmium and Ginkgo biloba. Biol Trace Elem Res. 2011; 140:330-341.

30. Mohamed D, Saber A, Omar A, Solima A. Effect of cadmium on the testes of adult albino rats and the ameliorating effect of zinc and vitamin E. British Journal of Science. 2014; 11(1):72-95.

31. Sinha SN. Phytochemical analysis and antibaterial potential of moringa oleifera lam. International Journal of Science Innovations and Discoveries. 2012; 2:401-407.

32. Ajibade TO, Arowolo R, Olayemi FO. Phytochemical screening and toxicity studies on the methanol extract of the seeds of Moringa oleifera. Journal of Complementary and Integrative Medicine, 2013; 10(1): 1-6.

33. Munirat AI, Mohammed SJ, Ademola MH, Parveen J. Moringa oleifera seed extract: A review on its environmental applications. International Journal of Applied Environmental Sciences. 2016; 11(6): 1469-1486.

34. Becho JMR, Peters VM, Macedo RM, Lucinda LMF, Guerra MO. Toxicological evaluation of the flavonoid rutin on the reproductive system of Wistar rats. Revista Interdisciplinar de Estudos Experimentias. 2015; 7: 7-14.

35. Maoxin C, Hao J, Yang Q, Li G. Effects of Icariin on reproductive functions in male rats. Molecules. 2014; 19: 9502-9514.

36. Gupta RS, Chaudhary R, Yadav RK, Verma SK, Dobhal MP. Effect of Saponins of Albizia lebbeck (L.) Benth bark on the reproductive system of male albino rats. J Ethnopharmacol. 2005; 96(1-2):31-6.
37. Jenkins R. Exercise and Oxidative stress methodology: a critique. Am J Clin Nutr. 2000; 72(2): 670S-674s.

38. Araujo ASR, Ribeiro MFM, Enzveiler A, Schenkel P, Fernandez TRG, Partata WA, Irigoyen MC, Bello-Klein A. Myocardial antioxidant enzyme activities and concentration and glutathione metabolism in experimental hyperthyroidism. Mol and Cell Endocrinol. 2006; 249:133-139. 39. Messarah M, Boulakoud M, Boumendjel A, Abdennour C, El Feki A. The impact ofthyroid activity variations on some oxidizing-stress parameters in rats. C. $R$. Biologies. 2007; 330: 107-112.

40. Adisa RA, Choudharyb MI, Olorunsogo OO. Hypoglycemic activity of Buchholzia coriacea (Capparaceae) seeds in streptozotocin-induced diabetic rats and mice. Elsevier Gmbh, Exp Toxicol Pathol. 2011; 63(7-8): 619-25

41. Petrulea M, Muresan A, Duncea I. Oxidative Stress and Antioxidant Status in Hypo and Hyperthyroidism. In Antioxidant enzyme (ed Mohammed Amr El-Missiry), 2012; pp. 197-233. InTech Open Access publishers. DOI: $10.5772 / 51018$

42. Yamaguchia S, Chiemi MC, Kikuchi K, Celino FT, Agusa T, Tanabe S, Takeshi MT. Zinc is essential trace element for spermatogenesis. PNAS., 2009; 106: 1085910864.

43. Halliwell B, Gutteridge JMC. Oxygen toxicity, oxygen radical transition metals and disease. Biochem J. 1984; 219: $1-14$.

44. Draper HH, Hadley M. Malodialdehyde determination as index of lipid peroxidation. Methods Ensymol. 1990; 186: 421-31.

45. Koyu A, Gokcimen A, Ozguner F, Bayram DS, Kocak A. Evaluation of the effects of Cadmium on Rat Liver. Molecular and Cellular Biochemistry, 2006; 284(1-85). 